\title{
NEW ZEALAND FAMILY LAW AND \\ INTERNATIONAL LAW - A COMMENT WITH SOME QUESTIONS
}

\author{
KJ Keith
}

\begin{abstract}
In this article, an addition to the issue in honour of Bill Atkin, Sir Kenneth Keith considers the growing impact of international law on family law in New Zealand. The article begins by broadly outlining shifts in society and legal approach that impact on the field of family law. This leads to a discussion of the Hague Conference on Private International law, the conventions that came out of the conference, and the extent of New Zealand's adoption of those conventions. The different ways in which these conventions have been implemented in national law, both historically and in the present day, are then addressed. The article concludes by noting New Zealand's failure to accede to various conventions touching on family law, and suggests that international law will yet have considerable impact in family law development.
\end{abstract}

\section{INTRODUCTION}

In this brief article, I look back over the growing impact of international law on family law. On first impression, especially in New Zealand, so distant from other countries, it is a very domestic subject. But further reflection on the greatly increased movement of family members and the distribution of family property across borders shows why it is that the international element has become much more prominent.

If I may go back to the mid-1950s when I was first a law student (and family law was not a distinct subject in the law degree and was largely administered under the Destitute Persons Act 1910 and the Domestic Proceedings Act 1939, while international law and conflict of laws were compulsory subjects) only about 1,500 people sailed or flew into and out of New Zealand each week. The figure

* Judge of the International Court of Justice (2006-2015); Judge of the New Zealand Court of Appeal and Supreme Court (1996-2006); Member of the New Zealand Law Commission (1986-1996); Member of the Law Faculty, Victoria University of Wellington (1962-1964, 1966-1991); Dean of the Law Faculty, Victoria University of Wellington (1977-1981); Professor Emeritus, Victoria University of Wellington (1991-); and Distinguished Fellow of the Law Faculty, Victoria University of Wellington (2015-). Thanks to Amelia Keene and Monique van Alphen Fyfe for research assistance and to Dr Hans van Loon, Chief District Court Judge Jan-Marie Doogue and Principal Family Court Judge LJ Ryan for comment. 
has increased almost 100 -fold to more than 100,000 . With the great increase in the international movement of individuals has also come a great increase in the diversity of the population, especially in Auckland with 44 per cent of its population having been born outside New Zealand, as marked recently by the launch there of the Superdiversity Centre for Law, Business and Government. Witi Ihimaera concludes his recent New Zealand Book Council lecture, "Where is New Zealand Literature Heading?", with the thoughts of Roger Horrocks: ${ }^{1}$

Roger thinks that, during our lifetimes, we have seen New Zealand pass through an extraordinary series of changes and reinventions. When he was growing up in the 1950s, the country still felt like a British colony. It was then transformed by many influences such as American culture, corporate capitalism, the Maori renaissance, the women's movement, gay rights, Pacific Island cultures, links with Australia, links with Asia. And now we are being reinvented once again by the digital revolution.

Among those international travellers may be family members moving permanently but with property and other rights and obligations (for example in respect of the payment of maintenance or child support to members of the family) in other countries; they may be moving with a child in breach of guardianship or custody orders; some of the travellers may have been adopted, legitimated, married or divorced or have entered into personal relationships abroad in accordance with the laws of a foreign country which differ from those where the individuals are now living.

How is the legal system to which one of those individuals, involved in a family dispute, turns to respond? To what connecting factor should that system be looking to determine the governing law? The law of the nationality, domicil or habitual residence of the persons involved (and which one) or simply to its own law? By whom is that law to be made or declared? By the international community through treaties, regionally or more broadly, by legislatures, by judges or by scholars? In chronological terms, that list should probably be reversed, with the scholars and judges in the lead. Joseph Story, the great American jurist, published the first edition of his pathbreaking Commentaries on the Conflict of Laws in $1834 .^{2}$ He needed about 200 pages to treat domicil, capacity of persons, marriage and divorce.

Story provides me with a convenient beginning. After an introductory chapter and a discussion of general maxims of international jurisprudence, he considers domicil because he will be making "perpetual reference ... to the domicil of the party". ${ }^{3}$ To come forward 125 years, Dr Donald Inglis,

1 Witi Ihimaera Where is New Zealand Literature Heading? (New Zealand Book Council, Te Kaunihera Pukapuka o Aotearoa, Wellington, 2015) at 32. Roger Horrocks is a filmmaker, biographer and one time professor of the University of Auckland.

2 Joseph Story Commentaries on the Conflict of Laws, Foreign and Domestic: In Regard to Contracts, Rights, and Remedies, and Especially in Regard to Marriages, Divorces, Wills, Successions, and Judgments (Hilliard Gray and Company, Boston, 1834).

3 At [40]. 
then a senior lecturer at the Faculty of Law at Victoria University of Wellington, in the first casebook on law published in New Zealand declared that the concept of domicil is of exceptional importance in "English Conflict of Laws" - shorthand, as he explained, for the English common law as applied in any particular Commonwealth country. ${ }^{4} \mathrm{He}$ did, however, recognise the problems with the law of domicil, especially the derivative domicil of married women, already long qualified in respect of divorce; jurisdiction had been available since 1898 on the basis of the parties' domicil at the time of desertion or when a separation agreement or decree was made. He also acknowledged that general legislative reform was in prospect. $^{5}$

A year later, in his book Family Law (1960), Dr Inglis stated that domicil is a concept which is of considerable importance throughout family law. ${ }^{6}$ In a number of respects it is a vital factor. ${ }^{7}$ Again he recognised the need for the particular changes which had been made but the abolition of derivative domicil altogether appeared "ill-advised". ${ }^{8}$ The "major changes" he feared were in fact made, although not until $1976 .{ }^{9}$ But by 2007, in his wide ranging review of New Zealand Family Law in the $21^{\text {st }}$ Century (2007), New Zealand's "preeminent family law jurist" (the words of Peter Boshier, then the Principal Family Court Judge), (now) Judge Inglis QC makes only one passing reference to domicil where residence is available as an alternative basis for jurisdiction ${ }^{10}$ and makes no reference at all to the comprehensive changes made in 1976, a major, if technical, instance of the fact that family law and practice had moved into a different era; transformed, developed and reinvigorated out of all recognition, ${ }^{11}$ a matter emphasised shortly before by Bill Atkin in his inaugural lecture, "Harmonising Family Law". ${ }^{12}$

4 BD Inglis Conflict of Laws (Sweet \& Maxwell, Wellington, 1959) at vi and 73.

$5 \quad$ For an unsuccessful challenge to early legislation which widened jurisdiction beyond domicil as not being for "the peace, order and good government of New Zealand" because it was in breach of international law see Worth $v$ Worth [1931] NZLR 1109 (CA). Notice also that AV Dicey published his book on Domicil some years before the first edition of 1896 of his major (still continuing) digest and that his treatment of domicil in that digest extended to almost 100 pages. See AV Dicey The Law of Domicil as a Branch of the Law of England Stated in the Form of Rules (Stevens and Sons, London, 1879) and AV Dicey A Digest of the Law of England with Reference to the Conflict of Laws (Stevens and Sons, London, 1896).

6 BD Inglis Family Law (Sweet \& Maxwell, Wellington, 1960).

7 At 15 .

8 At 23.

9 WR Atkin "The Domicile Act 1976" (1977) 7 NZULR 286.

10 BD Inglis New Zealand Family Law in the 21st Century (Thomson Reuters, Wellington, 2007) at [15.2].

11 At ix.

12 WR Atkin "Harmonising Family Law" (2006) 27 VUWLR 465. See also for example the Family Proceedings Act 1980, s 44. 


\section{THE HAGUE CONFERENCE ON PRIVATE INTERNATIONAL $L A W$}

I have mentioned Story's path-breaking (in the common law at least) text, published in the first half of the nineteenth century. Dicey's first edition of his very influential English text did not appear until near the end of that century. ${ }^{13}$ At the same time, the need for international action was recognised, particularly by Tobias Asser (1828-1913), an eminent Dutch jurist and the youngest of the founding members of the Institut de Droit International in 1873. It was Asser's work that led to the first four interstate conferences in The Hague on private international law. As president of the first session he declared at the outset that he could not hide the deep emotion which he felt at the beginning of this work; it had been one of the dreams of his youth. ${ }^{14}$ The importance of this work was marked by his award of the Nobel Peace Prize in 1911. The Chair of the Norwegian Nobel Committee saw him as a practical legal statesman and a pioneer in the field of international legal relations comparable to Hugo Grotius. The crown on his public activity as a diplomat, lawyer and scholar was his chairing of the four conferences which prepared seven conventions on civil procedure and family matters, conventions which would lead to greater public security and justice in international relations. ${ }^{15}$ In 2012 the University of Amsterdam celebrated the 150th anniversary of his inaugural lecture with a seminar and by publishing that lecture with an excellent introductory essay by a former Minister of Justice, Ernst Hirsch Ballin. ${ }^{16}$ Those early conferences were attended by delegations from European continental civil law countries with a Japanese delegation attending the last.

It was only after the Second World War that a permanent organisation was established; its membership now consists of 79 countries from all parts of the world and the European Union and another 68 non-member States have become parties to the 40 conventions adopted in the post war period. There is now a serious question concerning the respective roles of the European Union and the Hague Conference in this area of law. ${ }^{17}$ New Zealand did not become a member of the Hague

13 Dicey A Digest of the Law of England with Reference to the Conflict of Laws, above $\mathrm{n} 5$.

14 See the tribute by the Director of the Asser Institute, CCA Voskuil, "Tobias Michael Casel Asser (18381913)" in Livre du Centenaire 1873-1973 [de l'Institut de Droit International]: évolution et perspectives du droit international (Bâle, 1973) 11.

15 See Hans van Loon "The Hague Conference on Private International Law: Asser's vision and an evolving mission" (2012) Nederlands Internationaal Privaatrecht 358; and Geert De Baere and Alex Mills "TMC Asser and Public and Private International Law: The Life and Legacy of 'a Practical Legal Statesman"' (2011) 42 NYIL 1.

16 EMH Hirsch Ballin "A Mission for his Time" in A mission for his time: Tobias Asser's inaugural address on commercial law and commerce, Amsterdam 1862 (TMC Asser Press, The Hague, 2012) at 1.

17 See for example P Beaumont "International Family Law in Europe - the Maintenance Project, the Hague Conference and the EC: A Triumph of Reverse Subsidiarity" (2009) 73 Rabels Z 509. For a broader view of the issues see Hans van Loon "Remarks on the Needs and Methods for Governance in the field of private 
Conference until 2002, having become a party to the Legalisation Convention in 2001, the Adoption Convention in 1999 and the Child Abduction Convention in $1991 .{ }^{18}$ Efforts had been made over a number of years to persuade those in Wellington with primary responsibility to consider becoming a member, a matter addressed much earlier by Campbell McLachlan. ${ }^{19}$ That timing creates a disadvantage: states which were not members when the abduction convention was adopted have rights and duties in respect of other parties only if the other party expressly agrees ${ }^{20}$ and in the case of the other two conventions the parties can object within six months and prevent the bilateral tie. (That objection possibility also exists in the 1996 Convention on the Protection of Children discussed later.) Not being involved in the work of the Hague Conference may also have been a factor in New Zealand's flawed legislative implementation of the Abduction Convention considered later. One positive outcome of that membership is the excellent contribution made over the past 10 years or so by individual New Zealanders participating in the work of the Conference in both the family and commercial areas, notably in recent years by Chief District Court Judge Jan Doogue and David Goddard QC.

Among other non-Hague Conference treaties relating to the family to which New Zealand is party are the International Covenant on Civil and Political Rights 1966 (ICCPR), the Convention on the Rights of the Child 1989 (CROC) and the Convention on the Recovery Abroad of Maintenance $1956 .{ }^{21}$ The first and second have featured particularly in cases and policies relating to immigration, as mentioned later.

\section{HOW TO DEAL WITH DIVERSITY, INTERNATIONALLY?}

One critical challenge facing those attempting to prepare conventions relating to family law is the huge variation, based on culture, religion and history, in family policy, practice and law across the world, quite apart from the rapid changes occurring within states as already mentioned for New Zealand. Is not the task impossible? Tobias Asser did not think so but he was considering only the

international law at the regional and global levels" in Fabrizio Caffagi and Horatia Muir Watt (eds) Making European Private Law: Governance Design (Edward Elgar Publishing, Cheltenham, 2010) 197.

18 Hague Convention Abolishing the Requirement of Legalisation for Foreign Public Documents 527 UNTS 189 (opened for signature 5 October 1961, entered into force 24 January 1965); Hague Convention on Protection of Children and Cooperation in respect of Intercountry Adoption 1870 UNTS 167 (opened for signature 29 May 1993, entered into force 1 May 1005); and Hague Convention on the Civil Aspects of International Child Abduction (opened for signature 25 October 1980, entered into force 1 December 1983).

19 Campbell McLachlan "Reforming New Zealand's conflicts process" (1984) 14 VUWLR 443.

20 For a recent instance see In the Matter of J (a child) [2015] UKSC 70, [2015] 3 WLR 1827 (SC).

21 International Covenant on Civil and Political Rights 999 UNTS 171 (opened for signature 16 December 1966, entered into force 23 March 1976); Convention on the Rights of the Child 1577 UNTS 3 (opened for signature 20 November 1989, entered into force 2 September 1990); and Convention on the Recovery Abroad of Maintenance 268 UNTS 3 (opened for signature 17 May 1955, entered into force 25 May 1957). 
civil law states of Continental Europe. Even within that area, to come to the present time, compare the refusal of Malta to countenance divorce (until 2011) with the easily available no fault system of Sweden. But those two countries have considered it possible to become parties to five of the treaties relating to family matters - abduction, adoption, and, in the context of their European Union Membership, child protection and two relating to child support and maintenance. The membership of the Hague Conference plus the non-member parties to conventions - almost 150 in all - includes several Moslem countries, the Holy See and a number of Asian states. And matters such as "nonmarried couples", same sex marriage and parentage/surrogacy are among those which the Conference has discussed in various contexts in recent years.

Two features of the conventions, among others, address the challenge of diversity. The first is that the conventions may avoid addressing the merits of the dispute but rather may limit themselves to determining the applicable national law. As early as 1902 the Convention on the Guardianship of Minors used "habitual residence" as a connecting factor and that practice has further evolved to the present day. ${ }^{22}$ In the words of the rapporteur in her explanatory report on the Abduction Convention: ${ }^{23}$

... we shall not dwell ... upon the notion of habitual residence, a well-developed conception in the Hague

Conference, which regards it as a pure matter of fact, differing in that respect from domicil.

The rapporteur on the Adoption Convention spoke similarly of the "factual character" of habitual residence. ${ }^{24}$ So the Abduction Convention requires the return of the child to their place of habitual residence, with some qualifications. ${ }^{25}$ Those qualifications - the second relevant feature addressing diversity - often take the form of a generally worded public order/ordre public exception; the Abduction Convention provides more specific qualifications - that there is a grave risk that the return of the child would expose the child to physical or psychological harm or otherwise place the child in an intolerable situation or that return would subject the child to violation of basic human rights and fundamental freedoms. The recently retired Secretary-General of the Hague Conference has remarked that the absence of such qualifications in the early marriage convention had the consequence that

22 Hague Convention relating to the settlement of guardianship of minors (opened for signature 12 June 1902, entered into force 30 July 1904).

23 Elisa Pérez-Vera Explanatory Report [to the Hague Convention on the Civil Aspects of International Child Abduction] (Madrid, 1981) at [66].

24 G Parra-Aranguren Explanatory Report on the Convention on Protection of Children and Co-operation in respect of Intercountry Adoption (Caracas, 1993) at [78]. See similarly SK v KP [2005] 3 NZLR 590 (CA) quoting the rapporteur on the Abduction Convention.

25 Recent decisions of the Supreme Court of the United Kingdom highlight the difficulties particular circumstances present in making that factual assessment. See for example $A R v R N$ [2015] UKSC 35, [2016] AC 760 referring to recent cases including one from the European Court of Justice. 
German racist marriage laws were applied under that convention. ${ }^{26}$ Tobias Asser had indeed anticipated the need for such exceptions at the very beginning of the Hague Conference. ${ }^{27}$

\section{NATIONAL IMPLEMENTATION}

A recurring issue for those responsible for the implementation of treaties in national law, including those in the family law area, is just how that implementation is to be achieved. How is legislation to be drafted, assuming it is considered necessary? That assumption, it might be noted, has not been made in respect of the CROC, nor, so far as family matters are concerned, in respect of the ICCPR, a matter to which I will return.

Changing attitudes to that question of drafting among officials, Ministers, parliamentary counsel and legislators can be seen in the legislation giving effect to the Abduction Convention.

The United Kingdom statute in issue in an early case did provide for the scheduled text to "have the force of law in the United Kingdom", but that scheduled text omits certain provisions of the Convention which the House of Lords nevertheless considered material. ${ }^{28}$ The omitted provisions included the preamble, the statement of objectives of the Convention, the provision concerning refusal of return if not permitted by the forum's fundamental principles of human rights and fundamental freedoms, and the provision limiting application of the Convention to wrongful removals and detentions after its entry into force (the matter actually in issue in the case). The omission did not impede the House's use of the full text (the leading speech emphasises the preamble and first article for instance), although that use does raise a question about the effectiveness in law of Parliament's selection of the relevant provisions; and the omission from the statute book at the least required an unnecessary reference by the parties, their advisers and the courts to a separate publication to access those other provisions they considered relevant.

Early litigation in New Zealand arose not from the deficiencies in the publishing of the Convention (for the whole text in English was scheduled to the statute), but rather from the failure to give it the direct force of law and the decision to use different words in the implementing statute. The Minister in charge of the Bill said that it implemented the Convention by setting up a statutory regime that reflected the provisions of the Convention. It had been drafted in this form to ensure that the interpretation difficulties raised by the language of the Convention were avoided. ${ }^{29}$ In one case the Court of Appeal was able, in the context of the particular facts, to read the legislation and the

26 van Loon, above n 15 , at 359.

27 Voskuil, above n 14, at 24-25.

28 In re H (Abduction; Custody Rights) [1991] 2 AC 476. Compare the extraordinary decision of the same court 60 years earlier which refused to look at the text of the Treaty which it had before it scheduled to the Act it was interpreting, Ellerman Lines Ltd v Murray [1931] AC 126.

29 (15 May 1990) 501 NZPD 1540. 
Convention consistently (the lower courts had not been so able) but as McKay $\mathbf{J}$ said in the Court of Appeal: ${ }^{30}$

It is unfortunate that for reasons which are not readily discernible the Act has departed from the wording of the Convention, instead of simply adopting it as has apparently been done in other countries. Some of the differences appear to be significant ....

The difficulties in the courts did lead to amending legislation which still did not give direct effect to the Convention and which was drafted before the judgments of the Court of Appeal were available to inform that process.

In later cases the courts have declared that they should endeavour to interpret the provisions of the Act consistently with the Convention: that follows from the title to the 1991 Act (it is enacted in order to implement the Convention) and from established authority. In addition, the growing body of case law and official and other commentary (including the report of the rapporteur on the Convention mentioned earlier) should assist in efforts to interpret the Convention in the same way as others do, in this matter of international concern. ${ }^{31}$ That emphasis is facilitated by the materials on the implementation of the conventions prepared by the Bureau of The Hague Conference, the meetings of Special Commissions which New Zealand judges and officials attend and meetings of the International Hague network of Judges in which New Zealand judges have long been active. ${ }^{32}$

In the latest statute designed to implement the Convention, its text is still not given the force of law. ${ }^{33}$ Why not? The Canadian, United Kingdom and United States legislatures long ago took that course. In an area as testing as this, should opportunities be given to the parties and their diligent counsel to find discrepancies between the texts if, as is plainly the case here, the conventions can be

30 Gross v Boda [1995] 1 NZLR 569 (CA) at 574.

31 Dellabarca v Christie [1999] 2 NZLR 548 (CA) at 551. See also for example Chief Executive of the Department for Courts v Phelps [2000] 1 NZLR 168 (CA) at 174 and 175 in which further difficulties arose from the differences between the legislation and the Convention. For other cases emphasising international consistency of interpretation see Punter v Secretary for Justice [2007] 1 NZLR 40 (CA) at [10]-[11] and [170]-[171] and Lozano v Montoya Alvarez 572 US (2014), citing among others HJ v Secretary for Justice [2006] NZFLR 1005 (CA) at [53]. The appeal was dismissed on other grounds; see HJv Secretary for Justice [2006] NZSC 97, [2007] 2 NZLR 289. See also Linda J Silberman "United States Supreme Court Hague Abduction Decisions: Developing a Global Jurisprudence" (2014) 9 J Comp Law 49.

32 For instance in the course of November 2015 there was New Zealand representation at an expert group meeting on Cross Border Recognition and Enforcement of Agreements in Family Matters involving Children, a global meeting on the recovery of child support and family maintenance and a meeting of the network of judges.

33 Care of Children Act 2004, pt 2, sub-pt 4. 
given direct force? By contrast the Hague Intercountry Adoption Convention is given the force of law. ${ }^{34}$

What is the value attained by the local drafting which is to be balanced against the costs and anguish caused by any resulting discrepancies and the resulting litigation? Not just in this area of law but in others there are instances of judges straining to remove the apparent discrepancies and to deny weight to the terms of the implementing legislation. ${ }^{35}$ While that judicial action is to be applauded, it too involves unnecessary costs to the state as well as to the parties.

Earlier I noted that, so far as matters of family law were concerned, the executive made the assessment that becoming party to the ICCPR and the CROC, as happened in 1979 and 1993 respectively, required no change to existing legislation. They made that assessment in terms of the standard practice and principle to the effect that treaty obligations will not be accepted unless and until national law, policy and practice meet those obligations. ${ }^{36}$ The basic proposition that the executive cannot change national law by entering into treaty obligations does not however mean that those obligations may not be relevant to the interpretation of legislation or the development of the common law. That may be seen from decisions from 150 and more years ago. It may also be seen much more recently in family law cases in which the ICCPR and CROC have been invoked. Even before that, in 1977, a court, in part by reference to international standards, struck down conditions, laid down by the Minister of Education governing the payment of removal expenses for teachers because they discriminated against married female teachers. ${ }^{37}$ There was no hint in the Education Act or the regulations that such discrimination based on sex alone was authorised. The Act, in a provision going back to 1938 when legislation was introduced to protect the rights of married women to become schoolteachers, indicated the contrary. ${ }^{38}$ And, said the judge, a reference to certain international documents, although not essential, was not out of place. He mentioned the Universal Declaration of Human Rights, the Declaration on the Elimination of Discrimination Against Women and the

34 Adoption (Intercountry Convention) Act 1997. See similarly Civil Aviation Act 1990 pt 9A; Sale of Goods (United Nations Convention) Act 1994; and Maritime Transport Act 1994, ss 209 and 216.

35 See for example Corocraft Ltd v Pan American Airways [1969] 1 QB 616 (CA) at 652, noted in KJ Keith "Treaties and Legislation" (1970) 19 ICLQ 127; and Attorney-General v Mobil Oil NZ Ltd [1989] 2 NZLR 649 (HC). The legislation in issue in the latter case has since been corrected in the 2000 amendment to the Arbitration (International Investment Disputes) Act 1979; Law Commission Arbitration (NZLC R20, 1991) at [158]-[163].

36 So far as the ICCPR is concerned legislation was enacted in respect of the non-retroactivity of criminal sanctions and deportation procedures and the government made four reservations; it made three reservations on ratifying the CROC. The making of the reservations avoided the need to legislate on those matters.

37 Van Gorkom v Attorney-General [1977] 1 NZLR 535 (SC) [Van Gorkom (SC)], affirmed by the Court of Appeal in Van Gorkom v Attorney-General [1978] 2 NZLR 387 (CA).

38 Education Act 1964, s 150; and see Van Gorkom (SC), above n 37, at 541. 
International Labour Organisation Equal Remuneration Convention. ${ }^{39}$ The subdelegated power being invoked, which was in somewhat general terms and on its face of an ancilliary and innocuous kind, should not without compelling reason be taken to allow the introduction of a policy conflicting with the spirit of the international standards proclaimed by the United Nations documents.

The willingness of New Zealand judges to refer to international material in that way waxed and waned in following decades as it did in other common law jurisdictions ${ }^{40}$ but following ratification of the ICCPR and CROC reference to, and judicial reliance on, international material has become more common and consistent. An early indication was provided in Tavita v Minister of Immigration when in an interim decision the Court of Appeal found as unattractive the argument that the Minister and Department were entitled to ignore the international instruments. ${ }^{41}$ Such an argument apparently implied that New Zealand's adherence to the international instruments had been at least partly window dressing. While the Court need not make a final decision on the argument there must be at least hesitation in accepting it. The law on the bearing of international human rights law on national law was undergoing evolution; the Court referred to statements adopted by Commonwealth judges in recent years. The appeal was adjourned to enable the appellant to make an application to the Minister and the Department. No doubt in such an application the international instruments would be referred to: the child at the centre of the case, a New Zealand citizen by birth, had been born after the Minister had made the relevant decision, a decision which also predated New Zealand's ratification of the CROC.

This is not an occasion to trace the later development of the relationship between national and international law and the now consistent application of the presumption or principle that legislation is to be interpreted consistently with international law if that is possible. Such accounts are readily available. ${ }^{42}$ In its family law manifestation that principle may also engage the 1951 Convention on the Status of Refugees. ${ }^{43}$ I would make only one point about that development, also to be seen beyond the area of family law. It is to record the very substantial changes of attitude, based on legal education

39 Van Gorkom (SC), above n 37, at 542. Universal Declaration of Human Rights GA Res 217/A/III (1948); Declaration on the Elimination of Discrimination Against Women GA Res 2263 (1967); Convention concerning Equal Remuneration for Men and Women Workers for Work of Equal Value (ILO Convention No 100) 165 UNTS 303 (opened for signature 29 June 1951, entered into force 23 May 1953).

40 See for example Kenneth Keith "New Zealand and International Law: 1963-2013" (2013) 25 NZULR 718 at 723-724; and James Crawford "International Law in the House of Lords and the High Court of Australia 1996-2008: a comparison" (2008) 28 Aust YBIL 1.

41 Tavita $v$ Minister of Immigration [1994] 2 NZLR 257 (CA).

42 See for example Claudia Geiringer "International Law through the Lens of Zaoui" (2006) 17 PLR 300; and Treasa Dunworth "Public International Law" 2000 NZ L Rev 217.

43 Convention on the Status of Refugees 189 UNTS 137 (opened for signature 14 December 1950, entered into force 22 April 1954). See for example Ye v Minister of Immigration [2009] NZSC 76, [2010] NZLR 104 at [24]-[27]. 
and related scholarship, as more and more lawyers have come to realise that much law is made elsewhere. ${ }^{44}$

\section{FURTHER QUESTIONS}

To conclude, I refer to some of the widely accepted family law conventions to which New Zealand is not a party:

- The 1996 Convention in respect of the protection of children (42 parties including Australia and the United Kingdom); ${ }^{45}$

- The 1973 and the two 2007 conventions on maintenance (32 parties including Australia and the United Kingdom, 28 including the United Kingdom, and 24 parties respectively); ${ }^{46}$

- The 1970 Convention on the recognition of divorces (20 parties including Australia and the United Kingdom) ${ }^{47}$ and

- The 1961 Convention on the form of wills (42 parties including Australia and the United Kingdom) and the 1973 UNIDROIT Convention providing a uniform law on the form of an international will (21 parties including Australia). ${ }^{48}$

In 2010 in a National Interest Analysis, the Ministry of Justice supported New Zealand acceding to the first Convention and the Foreign Affairs, Defence and Trade Committee of the House of Representatives in its report that year encouraged the Government to accede to the Convention at its earliest convenience. ${ }^{49}$ The Convention was seen as an important supplement to the two Conventions

44 See for example TH Bingham "There is a World Elsewhere: The Changing Perspectives of English Law" (1992) 41 ICLQ 513.

45 Convention on Jurisdiction, Applicable Law, Recognition, Enforcement and Co-operation in Respect of Parental Responsibility and Measures for the Protection of Children 2204 UNTS 95 (opened for signature 19 October 1996, entered into force 1 January 2002).

46 Convention on the Law Applicable to Maintenance Obligations 1056 UNTS 109 (opened for signature 2 October 1973, entered into force 1 October 1977); Convention on the International Recovery of Child Support and Other Forms of Family Maintenance (opened for signature 23 November 2007, entered into force 1 January 2013); and the Protocol on the Law Applicable to Maintenance Obligations HCCH (opened for signature 23 November 2007, entered into force 1 August 2013).

47 Convention on the Recognition of Divorces and Legal Separations 978 UNTS 393 (opened for signature 1 June 1970, entered into force 24 August 1975).

48 Convention on the Conflicts of Laws Relating to the Form of Testamentary Dispositions (opened for signature 5 October 1961, entered into force 5 January 1964); and Convention Providing a Uniform Law on the Form of an International Will 12 ILM 1298 (opened for signature 26 October 1973, entered into force 9 February 1978).

49 Extended National Interest Analysis: Hague Convention on Jurisdiction, Applicable Law, Recognition, Enforcement and Co-operation in Respect of Parental Responsibility and Measures for the Protection of Children (Ministry of Justice, 2010) at 1; and Foreign Affairs, Defence and Trade Committee International 
to which New Zealand is already party. Accession, said the Committee, would also simplify the handling of disputes involving family members in Australia. While other priorities in the family law area have held the necessary legislation back, there are signs that it may soon appear.

Australian state legislation relating to succession to property on death, in their provisions relating to the validity of wills executed in a foreign place, gives direct effect to the 1961 Convention and to the 1973 UNIDROIT Convention. ${ }^{50}$ By contrast the New Zealand Wills Act contains no rules applicable to the validity of wills made outside New Zealand but rather confers a power on the High Court to declare valid a document which appears to be a will if satisfied that it expresses the deceased person's testamentary intentions. ${ }^{51}$ The various Australian state provisions about formal validity were designed to remove difficulties arising from different state and foreign requirements. Is there good reason for New Zealand not taking the same action and becoming party to the 1961 and 1973 Conventions? Would that not simplify the administration of certain deceased estates particularly where there is a trans-Tasman element?

Similar questions may be asked about the maintenance/child support conventions; Judge Doogue played a major role in the preparation of the most recent two. New Zealand has since 1986 been party to the 1956 UN Convention on the Recovery Abroad of Maintenance but the Hague texts were designed to build on and to replace it. ${ }^{52}$

Challenging questions will continue to arise for Bill Atkin and his colleagues in the wider family law community, within the Hague Conference context, in respect, for instance, of the Conference's surrogacy/parentage project and the private international law issues surrounding the status of children. So New Zealand has recently answered a lengthy questionnaire in that broad area in which other international bodies such as the Committee on the Rights of the Child and the European Court of Human Rights are also engaged. As the facts and national and international policies and attitudes in this area continue to change testing issues of legal method will present themselves, notably in respect of the updating of the treaty texts - is it to be by judicial interpretation, administrative measures, protocols to the original text amending it, supplementary conventions or outright replacement? Instances of all may be found in respect of the Hague Conference texts and in other areas of internationalised private law.

treaty examination of the Convention on Jurisdiction, Applicable Law, Recognition, Enforcement and Cooperation in respect of Parental Responsibility and Measures for the Protection of Children (29 July 2010).

50 For example Succession Act 2006 (NSW), s 48 and pt 2.4A; Wills Act 1997 (Vic), s 17 and Div 7; Wills Amendment (International Wills) Act 2012 (Tas); Wills Act 1936 (SA), pt 3A; Wills Act 1970 (WA), pt XA; Succession Act 1981(Qd), Div 6A; Wills Act (NT), pt 5A; Wills Act 1968 (ACT), ss 15C and pt 3B.

51 Wills Act 2007, s 13.

52 See pt 8 of the Family Proceedings Act 1980. 
International law, it seems, will have a greater and greater role in family law matters. To adapt Matthew Arnold, yet again, it is important to see things steadily and to see them whole. ${ }^{53}$

53 Matthew Arnold "To a Friend" The Poems of Matthew Arnold, 1840-1867 (Oxford University Press, London, 1922) 40. The first principal function of the Law Commission is to take and keep under review in a systematic way the law of New Zealand; Law Commission Act 1985, s 5(1)(a). In the past the Commission has organised meetings of Government agencies with responsibilities in respect of international law making. 
(2016) 47 VUWLR 